\title{
KONSTRUKSI I'LAN AL-NIKAH DALAM FIQH PANCASILA (Telaah Pencatatan Perkawinan Perspektif Sad Al-Dzariah)
}

\author{
Mujiburrohman \\ Program Studi Hukum Keluarga Islam, STAI Miftahul Ulum Pamekasan \\ Email: mujibur.rohman6568@gmail.com
}

Mohsi

STAI Miftahul Ulum Pamekasan

Email: silamohsi@gmail.com

\begin{abstract}
Abstarak
The law on marital registration has juridical consequences, that marriage registration is a necessity of continuing legal actions in the form of marriage. Munakahat Fiqh does not know the name of marriage registration. The existence of marriage registration legislation creates a gap (dispute / conflict) between the law of fiqh munakahat with statutory regulations. in figh there is no registration of marriage. It's just that, for the sake of benefit and to avoid things mudarat, then Islam (figh) recommends the existence of i'l al-nikâh (announcing marriage) which is then manifested in the form of wedding celebrations (walimah al-shursh). Marriage that is not recorded at the competent authority raises many conditions, so that marriage registration is considered as a preventive measure (prevention) from the government as sadd al-dharî'ah (blocking the road).
\end{abstract}

Kata Kunci: Perkawinan, Pencatan Perkawinan, Sadd al-Dharìah.

\section{Pendahuluan}

Perkawinan yang dalam Islam dikenal dengan pernikahan bukanlah hal yang sakral lagi, praktik ibadah yang menyatukan kaum adam dengan kaum hawa dalam ikatan suami-istri sebagai ikatan mîthâqan ghalizan, hal ini sesuai dengan pasal 2 Kompilasi Hukum Islam (KHI) yang berbunyi: "perkawinan menurut bukum islam adalah pernikahan, yaitu adalah akad yang sangat kuat atau mithâqan ghaliżan untuk. mentaati perintah Allah dan melaksanakannya merupakan ibadab".

Hukum Islam yang telah dirumuskan menjadi hukum fiqh tidak boleh statis dalam penormaannya, perkembangan zaman dan teknologi memberikan ruang bagi para pemikir hukum Islam untuk terus berupaya

\footnotetext{
${ }^{1}$ Tim Redaksi Nuansa Aulia, Kompilasi Hukum Islam (Bandung: Nuansa Aulia, 2015), 2. 
memberikan rumusan rumusan hukum yang responsif, sehingga apatisme hukum dapat sirna dan taklid yang membabi buta bisa diminimalisir. ${ }^{2}$ Adapun hubungannya dengan hukum perkawinan Islam (hukum fiqh munakahat), secara prinsip sebenarnya tidak terdapat perbedaan antara hukum yang terdapat dalam undang-undang perkawinan dengan aturan hukum yang ada dalam kitab fiqh munakahat. Perbedaan yang nampak antara kedua aturan hukum tersebut hanya terletak pada syarat-syarat formal. ${ }^{3}$ Misalnya secara administratif perkawinan harus dicatatkan di Kantor Urusan Agama (KUA), agar mempunyai kekuatan hukum. Dalam kitab-kitab fiqh klasik, belum ada yang membincangkan pentingnya pencatatan perkawinan oleh petugas yang diberi kuasa oleh pemerintah (Ulil al-Amr), yaitu Pegawai Pencatat Nikah (PPN) untuk orang Islam dan Kantor Catatan Sipil (KCS) bagi non-muslim. Ada kemungkinan ketika kitab-kitab fiqh itu ditulis tahap kesadaran beragama dan tahap kejujuran serta keikhlasan kaum muslimin pada waktu itu masih tinggi, sehingga kemungkinan terjadinya penyalah gunaan institusi perkawinan sangat sedikit. ${ }^{4}$

Mengenai Undang-Undang pencatatan perkawinan, hal ini sudah ada dalam Pasal 1 ayat (1) dan (2) Undang-Undang Nomor 22 Tahun 1946 tentang Pencatatan Nikah Talak dan rujuk. ${ }^{5}$ Secara tekstual pencatatan perkawinan memang tidak pernah dibahas dalam kitab-kitab fiqh klasik manapun. Namun, secara kontekstual pencatatan perkawinan merupakan bentuk manifestasi dari i'lân al-nikâh. Mengenai i'lân al-nikâh sendiri merupakan bentuk mengumumkan sebuah pernikahan agar tidak berjalan secara rahasia. Selain itu Pencatatan perkawinan, memang menjadi diskursus yang tidak akan pernah ada keringnya, selain karena factor legal normatif hokum Islam ansich yang tidak secara tersurat menyebutnya, juga dalam perspektif skeptic-

2 Mohsi, Mohsi. "KONSTRUKSI HUKUM PERCERAIAN ISLAM DALAM FIQH INDONESIA." Ulumuna: Jurnal Studi Keislaman 1.2 (2015). 237. http://ejournal.kopertais4.or.id/madura/index.php/ulumuna/article/view/1625

${ }^{3}$ Taufiqurrohman Syahuri, Legislasi Hukum Perkawinan di Indonesia; Pro-Kontra Pembentukannya Hingga Putusan Mabkamab Konstitusi (Jakarta: Kencana Prenada Media Group, 2013), 10-11.

${ }^{4}$ Arif Marsal \& Ryna Parlyna, "Pencatatan Perkawinan; Antara Rukun Nikah dan Syarat Administratif”, an-Nur, Vol. 4, No.1 (2015), 45.

${ }^{5}(1)$ "Nikah yang dilakukan menurut agama Islam, selanjutnya disebut nikah, diawasi oleh pegawai pencatat nikah yang diangkat oleh Menteri Agama atau pegawai yang ditunjuk olehnya. Talak dan rujuk yang dilakukan menurut agama Islam, selanjutnya disebut talak dan rujuk, diberitahukan kepada pegawai pencatat nikah". (2) "Yang berhak melakukan pengawasan atas nikah dan menerima pemberitahuan tentang talak dan rujuk hanyalah pegawai yang diangkat oleh Menteri Agama dan pegawai yang ditunjuk olehnya". Lihat: Undang-Undang Republik Indonesia Nomor 22 Tabun 1946 Tentang Pencatatan Nikab, Talak dan Rujuk. 
prajudice merupakan produk hokum yang secara peraturan perundangperundangan ada unsur ekploitasi hukum. ${ }^{6}$

Perkawinan di bawah tangan, yang tidak dicatatkan dipandang tidak mematuhi ketentuan peraturan perundang-undangan dan seringkali menimbulkan dampak negatif (madarrab) terhadap istri dan atau anak yang dilahirkannya terkait dengan hak-hak mereka seperti nafkah, hak waris dan lain sebagainya. Tuntutan pemenuhan hak-hak tersebut manakala terjadi sengketa akan sulit dipenuhi akibat tidak adanya bukti catatan resmi perkawinan yang sah. ${ }^{7}$ Oleh karenanya pencatatan perkawinan merupakan langkah preventif (pencegahan) untuk menolak dampak negatif yang terjadi. Dengan demikian hal ini diharamkan karena saddan li al-dharìah.

\section{Pencatatan Perkawinan Dalam Fiqh Pancasila}

Pencatatan perkawinan merupakan bagian dari syarat administratif yang telah ditentukan dalam undang-undang perkawinan dan Kompilasi Hukum Islam (KHI), namun pengertian pencatatan perkawinan dalam undang-undang No.1 Tahun 1974 tentang Perkawinan tidak dijelaskan secara rinci. Menurut Kamus Besar Bahasa Indonesia (KBBI), kata "Pencatatan" diambil dari kata "catat", yang mempunyai arti menuliskan sesuatu untuk peringatan. Sedangkan makna dari pencatatan yaitu proses, cara, perbuatan mencatat atau pendaftaran. ${ }^{8}$ Jadi, dapat diambil pemahaman bahwa pencatatan perkawinan merupakan sebuah proses input data atau pendataan mengenai sebuah pernikahan yang akan dan sudah dilangsungkan.

Neng Djubaidah mengemukakan bahwa pencatatan perkawinan merupakan pencatatan atas suatu perkawinan yang sah menurut hukum Islam, yaitu perkawinan yang memenuhi rukun dan syarat perkawinan sesuai syari'at Islam yang dilakukan di Kantor Urusan Agama (KUA) kecamatan setempat.' Ali Firdaus membedakan antara pengertian pencatatan nikah dengan pencatatan perkawinan, yang dimaksud pencatatan nikah adalah kegiatan menulis yang dilakukan seseorang mengenai suatu peristiwa pernikahan yang terjadi. Sedangkan pencatatan perkawinan adalah suatu tindakan hukum mencatat pernikahan oleh Pegawai Pencatat Nikah untuk

${ }^{6}$ Mohsi, Mohsi. "PENCATATAN PERKAWINAN SEBAGAI REKONSEPTUALISASI SYSTEM SAKSI PERKAWINAN BERBASIS MASLAHAH." Al-'Adalab: Jurnal Syariah dan Hukum Islam 4.2 (2019): 134.

${ }^{7} \mathrm{M}$. Asrorun Ni'am Sholeh, Metodologi Penetapan Fatwa Majelis Ulama Indonesia; Penggunaan Prinsip Pencegahan dalam Fatwa (t.tp: Emir, 2016), 223.

${ }^{8}$ Departemen Pendidikan Nasional, Kamus Besar Bahasa Indonesia (Jakarta: Gramedia Pustaka Utama, 2008), 247.

${ }^{9}$ Neng Djubaidah, Pencatatan Perkawinan dan Perkawinan Tidak. Dicatat Menurut Hukum Tertulis di Indonesia dan Hukum Islam (Jakarta: Sinar Grafika, 2012), 3. 
selanjutnya diwujudkan dalam bentuk akta dijadikan sebagai bukti sah terjadinya peristiwa pernikahan. ${ }^{10}$

Menurut Abdul Manan, yang dimaksud pencatatan perkawinan adalah kegiatan menulis yang dilakukan oleh seseorang mengenai suatu peristiwa yang terjadi. Abdul Manan juga berpendapat bahwa pencatatan perkawinan sangatlah penting, sebab buku nikah yang diperoleh merupakan bukti otentik tentang keabsahan pernikahan itu, baik secara agama maupun negara. ${ }^{11}$

Pencatatan perkawinan di Indonesia merupakan hal yang sangat diprioritaskan hal ini terbukti dengan adanya perundang-undangan mengenai pencatatan perkawinan. Seperti Undang-Undang Nomor 22 Tahun 1946 tentang Pencatatan Nikah Talak dan rujuk. Dalam Pasal 1 ayat (1), "Nikah yang dilakukan menurut agama Islam, selanjutnya disebut nikah, diawasi oleh pegawai pencatat nikah yang diangkat oleh Menteri Agama atau pegawai yang ditunjuk olehnya. Talak dan rujuk yang dilakukan menurut agama Islam, selanjutnya disebut talak dan rujuk, diberitabukan kepada pegawai pencatat nikab". ${ }^{12}$ Begitu pula dalam Kompilasi Hukum Islam (KHI) pasal 5 ayat (1) berbunyi: "Agar terjamin ketertiban perkawinan bagi masyarakat Islam setiap perkawinan harus dicatat". ${ }^{13}$

Sementara pada pasal 2 ayat (1) Undang-Undang No. 1 tahun 1974 tentang Perkawinan disebutkan, "Perkawinan adalah sab, apabila dilakukan menurut hukum masing-masing agamanya dan kepercayaannya itu". Kemudian dalam pasal 2 ayat (2), "Tiap-tiap perkawinan dicatat menurut peraturan perundangundangan yang berlaku". ${ }^{4}$ Sesuai dengan Peraturan Pemerintah (PP) No. 9 Tahun 1975 tentang pelaksanaan undang-undang nomor 1 tahun 1974 tentang perkawinan, bahwa pencatatan perkawinan dilakukan oleh Pegawai Pencatat Nikah. ${ }^{15}$ Proses pencatatan perkawinan dimulai dengan: Pertama,

${ }^{10}$ Ali Firdaus, "Pelaksanaan Tugas Pembantu Pegawai Pencatat Nikah Pasca Instruksi Dirjen Bimas Islam Nomor DJ.II/1 Tahun 2015”, Ijtimaiyya: jurnal Pengembangan Masyarakat Islam, Vol. 10, No. 2 (2017), 245.

${ }^{11}$ Dyah Ochtorina Susanti \& Siti Nur Shoimah, "Urgensi Pencatatan Perkawinan (Perspektif Utilities)”, Rechtidee, Vol. 11. No. 2 (Desember 2016), 172.

${ }^{12}$ Undang-Undang Republik. Indonesia Nomor 22 Tabun 1946 Tentang Pencatatan Nikab, Talak dan Rujuk.

${ }^{13}$ Tim Redaksi Nuansa Aulia, Kompilasi Hukum Islam..., 2.

${ }^{14}$ Penjelasan terhadap pasal 2 ayat (1 dan 2) UU No. 1 Tahun 1974 tentang Perkawinan, "Dengan perumusan pada Pasal 2 ayat (1) ini, tidak ada perkawinan di luar hukum masing-masing agamanya dan kepercayaan itu, sesuai dengan Undang-Undang Dasar 1945", dan "yang dimaksud dengan bukum masing-masingagamanya dan kepercayaanya itu termasuk. ketentuan perundang-undangan yang berlaku bagi golongan agamanya dan kepercayaanya itu sepanjang tidak bertentangan atau tidak ditentukan lain dalam Undang-Undang ini”. Team Citra Umbara, Undang-Undang RI Nomor 1 Tabun 1974 Tentang Perkawinan \& Kompilasi Hukum Islam (Bandung: Citra Umbara, 2017), 32.

${ }^{15}$ Pasal 2 ayat (1 dan 2) PP No. 9/1975 tentang pelaksanaan undang-undang nomor 1 tahun 1974 tentang perkawinan. 
pendaftaran kehendak nikah oleh masing-masing calon mempelai kepada pegawai pencatat nikah. ${ }^{16}$ Kedua, pemeriksaan berkas kehendak nikah serta pengumuman akad nikah. ${ }^{17}$ Ketiga, pelaksanaan pencatatan perkawinan. ${ }^{18}$ Keempat, penyerahan akta nikah.

Pernikahan yang tidak dicatatkan pada instansi berwenang seringkali merugikan berbagai pihak utamanya perempuan dan anak yang lahir dari pernikahan tersebut. Kegigihan kaum perempuan dalam memperjuangkan hak-haknya dalam persoalan perkawinan itu didasarkan pada adanya praktik-praktik perkawinan yang buruk dikalangan masyarakat, yang banyak menjadi korban ketidak adilan adalah kaum perempuan. Kasus perkawinan nikâh siri (rahasia) ${ }^{19}$ atau nikah bawah tangan ${ }^{20}$ yang terjadi pada tahun 2007 antara Nasrudin Zulkarnain (NZ) direktur PT. Rajawali Jakarta, dengan Rhani Juliani (RJ) di lapangan Golf Tangerang yang berakhir dengan tragis dengan ditembak matinya NZ oleh suruhan Antasari Azhar (AA), mantan ketua Komisi Pemberantasan Korupsi (KPK) dalam kasus cinta segitiga. ${ }^{21}$

Kasus perkawinan usia dini dan sirri yang terjadi pada tahun 2006, antara putra mahkota kerajaan kelantan Malaysia, Tengku Temenggong

\footnotetext{
16Pasal 3 PP No. 9/1975.

${ }^{17}$ Pasal 6 sampai 8 PP No. 9/1975.

${ }^{18}$ Pasal 10 dan 11 PP No. 9/1975.

${ }^{19}$ Secara etimologi, kata "siri" diambil dari bahasa arab, yaitu "sirrun" yang mempunyai arti rahasia, sunyi, diam, tersembunyi sebagai perlawanan dari kata "alaniyab" yang artinya terangterangan. Mengenai pengertian "nikâh siri" sendiri terdapat banyak pendapat ada yang mengatakan nikah tanpa wali, ada yang mengatakan nikah yang sah secara agama namun tidak dicatatkan di dalam instansi berwenang seperti Kantor Urusan Agama (KUA) bagi umat Islam dan Catatan Sipil bagi non-muslim. Selain itu, ada pula pendapat bahwa nikêh siri adalah nikah secara sembunyi karena berbagai pertimbangan misalnya, menikah dengan wanita sebagai isteri kedua yang dilakukan secara sembunyi karena tidak mau mendapatkan stigma negatif dari masyarakat. Mengenai sah atau tidaknya praktik nikâh siri, ulama sepakat bahwa nikâh siri tetap sah atau legal asal syarat dan rukun suatu pernikahan terpenuhi namun bila tidak terpenuhi salah dari rukun pernikahan maka hukumnya jelas tidak sah. Lihat: Ahmad Warson Munawwir, al-Munawir; Kamus Arab-Indonesia (Surabaya: Pustaka Progressif, 1997), 626. Bandingkan Vivi Kurniawati, Nikah Siri (Jakarta: Rumah Fiqih Publishing, 2019), 10-14.

${ }^{20}$ K.H. Ma'ruf Amin mengatakan bahwa istilah nikah di bawah tangan digunakan untuk mebedakan antara pernikahan siri yang dikenal oleh masyarakat, serta istilah ini lebih sesuai dengan ketentuan agama islam. Sesuai dengan hasil keputusan forum ijtima' ulama komisi fatwa bahwa yang di maksud nikah di bawah tangan adalah pernikahan yang terpenuhi semua rukun dan syarat yang ditetapkan dalam fiqh (hukum Islam). Namun, nikah tersebut tanpa pencatatan resmi di instansi berwenang sebagai mana diatur dalam perundang-undangan. Lihat: M. Asrorun Ni'am Sholeh, Metodologi Penetapan Fatwa Majelis Ulama Indonesia; Penggunaan Prinsip Pencegahan dalam Fatwa (t.tp: Emir, 2016), 222-223.

${ }^{21}$ Kurnia Muhajarah, "Secercah Pandang mengungkap Nikah Sirri di Indonesia", Sawwa, Vol. 10, No. 2 (April 2015), 256.
} 
Muhammad Fakhry (31 tahun) dengan Manohara Odelia Pinot (16 tahun), wanita keturunan Perancis Indonesia berakhir dengan perceraian pada tahun 2008. ${ }^{22}$ Baru-baru ini sebuah kasus datangnya dari artis Nikita Mirzani yang memang tak pernah lepas dari konflik pernikahan, selain konflik dengan Dipo Latief, Nikita Mirzani juga diketahui bermasalah dengan Sajad Ukra. Konflik pernikahan Nikita Mirzani dengan Dipo Latief mengakibatkan anak yang lahir dari pernikahan di bawah tangan antara keduanya tidak bisa diakui secara perdata (negara) dan menuai berbagai konflik hingga hak asuh dan biaya hidup anak tersebut harus ditanggung Nikita Mirzani. ${ }^{23}$

Berkaitan dengan hal tersebut, diharapkan setiap orang yang akan melaksanakan pernikahan agar tidak hanya meningkatkan aspek agama saja, tetapi juga perlu diperhatikan aspek-aspek keperdataan secara seimbang. Pencatatan perkawinan merupakan usaha pemerintah untuk mengayomi masyarakat demi terwujudnya kemaslahatan dari sebuah pernikahan. Karena hukum positif telah menentukan bahwa satu-satunya bukti adanya pernikahan adalah akta nikah, maka pencatatan perkawinan sangatlah perlu dilakukan untuk mendapatkan akta yang otentik, yaitu akta yang dibuat oleh Pegawai Pencatat Nikah (PPN). Akta otentik mempunyai kekuatan bukti yang sempurna atau bersifat mengikat bagi pihak manapun.

\section{Konsep Pencatatan Perkawinan dalam Fiqh Oriented}

Pada dasarnya konsep pencatatan perkawinan merupakan suatu bentuk pembaruan yang dilakukan dalam bidang hukum keluarga Islam. Hal ini disebabkan oleh tidak diungkapnya keharusan pencatatan perkawinan di dalam al-Qur'an dan hadis. Atas dasar inilah, para ulama fiqh juga tidak memberikan perhatian serius terhadap pencatatan perkawinan. Ada beberapa hal yang dianggap sebagai faktor penyebab pencatatan perkawinan luput dari perhatian para ulama pada masa awal Islam. Pertama,adanya larangan dari Rasulullah untuk menulils sesuatu selain al-Qur'an. Tujuannya untuk mencegah tercampurnya al-Qur'an dari yang lain. Akibatnya, kultur tulils tidak begitu berkembang dibandingkan dengan kultur hafalan (oral). Kedua, sebagai kelanjutan dari yang pertama, mereka sangat mengandalkan ingatan (hafalan). Agaknya mengingat suatu peristiwa perkawinan bukanlah hal yang sulilt untuk dilakukan. Ketiga, tradisi walimah al-ursh yang dilakukan dianggap telah menjadi saksi sharî tentang suatu perkawinan. Berdasar hal tersebut,

\footnotetext{
${ }^{22}$ Kurnia Muhajarah, "Secercah Pandang mengungkap..., 256.

${ }^{23}$ https://m.liputan6.com/showbiz/read/4048015/nikita-mirzani-tak-kapok-kapok-menikahsiri, diakses 23 September 2019.
} 
pada masa awal Islam, pencatatan perkawinan sebagai alat bukti yang autentik belum lagi dibutuhkan. ${ }^{24}$

Walaupun demikian, Praktek i’lân al-nikâh pada masa awal Islam merupakan salah satu hal yang disunnahkan dan sangat dianjurkan oleh Rasulullah SAW. Hal ini terbukti dengan adanya hadis yang menyatakan adanya i'lân al-nikâh (mengumumkan pernikahan) tersebut. Seperti hadis yang diceritakan oleh 'Âmir bin Abdullâh bin Zubair.

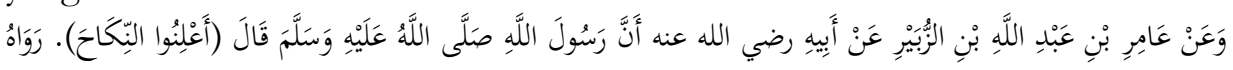

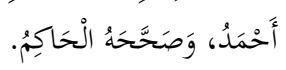

Artinya: Dicertakan hadiht dari Âmir bin Abdullâh bin Zubair dari bapaknya bahwa Rasulullah SAW. berkata: "Umumkanlah sebuah pernikahan". Hadis riwayat imam Ahmad dan dianggap șahih oleh imam Hâkim. ${ }^{25}$

Melihat adanya hadis di atas, terlihat bahwa adanaya i'lân al-nikâh merupakan bentuk praktis dan sederhana dalam mengumumkan pernikahan kepada khalayak ramai, hal ini bertujuan memberi tahu keberlangsungan sebuah pernikahan agar terkesan tidak menjadi rahasia secara aspek sosial. Melihat adanya i'lân al-nikeâh ini, dapat dipelajari bahwa spirit dan substansi yang ingin dicapai dari pencatatan perkawinan telah dimanifestasikan, meski dalam bentuk yang sederhana. Kemudian i'lân al-nikeâh dimanifestasikan

${ }^{24}$ Amiur Nuruddin dan Azhari Akmal Tarigan, Hukum Perdata Islam di Indonesia; Studi Kritis Perkembangan Hukum Islam dari Fikih, UU No. 1/1974 sampai KHI, (Jakarta: Kencana, 2004), 121.

${ }^{25}$ Siti ‘Âishah R.A. meriwayatkan sebuah hadis dengan esensi yang sama namun dalam redaksi yang berbeda:

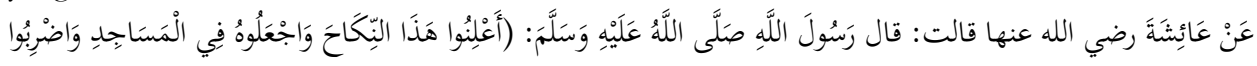

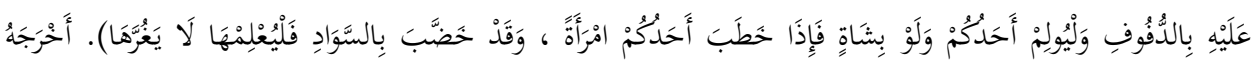

Artinya: Diceritakan hadis dari 'Aishab R. A. beliau berkata: Rasulullah SAW. bersabda: "Umumkanlah sebuah pernikahan itu dan jadikanlah tempat pengumumannya di masjid-masjid dan tabublah rebana-rebana dan adakanlah sebuah pesta pernikahan (walimah) walau banya dengan satu kambing, maka bila kalian melamar seorang wanita, dan berilah tanda dengan warna hitam, lalu adakan walimah dan jangan rahasiakan”. Hadis dikeluarkan oleh imam al-Tirmidhi. Lihat Muhammad bin Ismâ'il al-Kaḥlani, Subulu al-Salâm Sharh Bulîgh al-Marâm fî Adillat al-Ahkâm, Juz. 3 (Beirut: Dar al-Fikr, t.t.), 114-115. Bandingkan Ibn Hajar al'Asqalâni, Bulùgh al-Marâm fí Adillat al-Ahkâm (Surabaya: Nurul Huda, t.t.), 211. 
dalam bentuk perayaan yang dikenal dengan walimah al-ursh (resepsi/pesta perkawinan $)^{26}$.

Menurut pendapat yang kuat i'lân al-nikâh merupakan salah satu syarat sahnya akad nikah. Artinya, apabila pernikahan tidak diumumkan, maka pernikahan tersebut tidak sah, bahkan menurut pendapat sebagian ulama, yang membedakan antara pernikahan dan perzinaan adalah bahwa pernikahan diumumkan sedangkan perzinaan tidak diumumkan. ${ }^{27}$ Ulama fiqh (fuqahâ') umumnya berpendapat bahwa hukum mengumumkan perkawinan bukanlah merupakan syarat, rukun, ataupun kewajiban dalam sebuah akad perkawinan. Hukum mengumumkan perkawinan adalah yundhabu (disunnahkan). ${ }^{28} \quad$ Sedangkan menurut imam al-Zuhri mengumumkan perkawinan hukumnya adalah suatu yang fard $u$. Menurut pendapat ini, meskipun sebuah pernikahan sudah terpenuhi syarat dan rukunnya, tetapi kalau tidak diumumkan maka pernikahan itu dipisahkan, begitu juga bila dua orang saksinya ikut merahasiakan kepada khalayak ramai, maka pernikahan itu harus dipisah. ${ }^{29}$

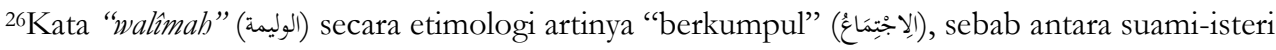
berkumpul. Walimah (الوليمة) berasal dari kata "al-Walmi" (الولم) yang artinya "makanan pengantin". Secara istilah yang dinamakan "walimah" (الوليمة) itu sendiri adalah nama dari setiap undangan atau makanan yang disediakan untuk mensyukuri kebahagiaan atau yang lainnya. Kata "walimab" (الوليمة) itu sendiri bila diucapkan secara mutlak maka yang di maksud adalah walimah al-ursh. Mengenai definisi walimah al-ursh yang sudah mashur dikalangan ulama diartikan dengan perhelatan dalam rangka mensyukuri nikmat Allah atas telah terlaksananya akad perkawinan dengan menghidangkan makanan. Mengenai hukum mengadakan walimah ada khilaf dikalangan ulama, terdapat dua hukum yang berbeda mengenai adanya pesta pernikahan (walimah). Pertama; hukum mengadakan walimah adalah sunnah, pendapat ini dikemukakan oleh Jumbûr al-Ulama golongan Madhhab Hanâfiyah, Shâfi'îyah dan Hanâbilah. selain itu, ulama Hanâfiyah juga menambahkan bahwa mengadakan pesta pernikahan (walimah) merupakan pahala yang besar. Sedangkan menurut ulama Mâlikîyah hukum mengadakan pesta pernikahan (walimah) adalah mandhûb. baik secara kecil-kecilan maupun secara besar-besaran sesuai kemampuan orang yang mengadakan perkawinan. Pendapat ini berlandaskan hadis walimah dengan memahami kata perintah (Amar) dalam hadis tersebut sebagai perintah wajib. Lihat: Nur Azizah Pulungan, Haruskah ada Walimah? (Jakarta: Rumah Fiqih Publishing, 2018), 20. Shams al-Dîn Muhammad bin Abi al-'Abbâs Ahmad bin Ḥamzah, Nihâyah al-Muhtaj ilâ Sharh al-Minhâj, Juz.6 (Beirut: Dar al-Kitâb al-'Tlmiyah, 2003), 369. Bandingkan Amir Syarifuddin, Hukum Perkawinan Islam di Indonesia; Antara Figh Munakahat dan Undang-Undang Perkawinan (Jakarta: Kencana Prenada Media Group, 2014), 156-157.

${ }^{27}$ Dian Mustika, "Pencatatan Perkawinan dalam Undang-Undang Hukum Keluarga di Dunia Islam", Inovatif; Jurnal Ilmu Hukum, Vol. 4. No. 5 (Juli, 2015), 54.

${ }^{28}$ Wizarah al-Auqâf wa al-Shu'ûn al-Islâmiyah, al-Mausu'ab al-Fiqhiyah, Juz. 41 (Kuwait: Wizarah al-Auqâf wa al-Shu'ûn al-Islâmiyah, 2002), 225.

${ }^{29}$ Vivi Kurniawati, Nikah Siri (Jakarta: Rumah Fiqih Publishing, 2019), 29.
} 
Berdasarkan pembahasan di atas, adanya i'lân al-nikâh, serta adanya anjuran Nabi dalam beberapa hadis atas diadakannya i'lân al-nikâh (mengumumkan perkawinan) dan anjuran dalam mengadakan pesta perkawinan (walimah) walau dalam bentuk sederhana. Hal ini menunjukkan spirit dan substansi yang ingin dicapai dalam melakukan pencatatan perkawinan, meskipun dalam bentuk berbeda namun dengan esensi pencapaian yang sama. Neng Djubaidah mengatakan bahwa adanya hadis "'shi'ar perkawinan" (i’lân al-nikệh) melalui pesta atau walimah adalah sebagai dasar hukum dilakukannya "pencatatan perkawinan", meskipun antara keduanya terdapat perbedaan makna. Bahkan Neng Djubaidah mengatakan bahwa peristiwa hukum perkawinan yang memenuhi rukun dan syarat, serta telah dicatatkan di KUA Kecamatan setempat, tetapi tidak dilakukan Shi'ar perkawinan melalui i'lân al-nikâh atau walìmah, kerap terjadi dalam masyarakat. Hal ini dapat menimbulkan fitnah pula. ${ }^{30}$ M. Atho' Mudzar mengatakan bahwa pencatatan perkawinan yang dilakukan saat ini harus dilihat sebagai bentuk baru dalam mengumumkan pernikahan (i'lân al-nikâhh). Lebih jauh lagi menurutnya, pencatatan perkawinan ini dianggap lebih mașlahah, terutama bagi perempuan dan anak-anak. ${ }^{31}$

Dalam kitab-kitab fiqh klasik, belum ada yang membincangkan pentingnya pencatatan perkawinan oleh Pegawai Pencatat Nikah (PPN) yang diberi mandat oleh pemerintah (ulil amri) dalam menangani hal tersebut. Pemerintah sebagai transformasi fungsi ulil amri berhak untuk dipatuhi oleh warganya, selama pemerintahanatau negara tersebut tidak mengajak kepada kemungkaran dan kemudaratan ${ }^{32}$.

Pada zaman Rasulullah SAW. setiap kejadian pernikahan, talak dan ruju' dan lain sebagainya selalu dihadapkan kepada Rasulullah, kemudian Rasulullah menghukum begini dan begitu, ini menandakan bahwa setiap peristiwa perkawinan dan perceraian selalu diketahui oleh Rasulullah SAW. Karena kedudukan Rasulullah sebagai ulama atau umara atau ulil amri. Memang pada zaman Rasulullah perkawinan dan perceraian tidak dicatatkan,

${ }^{30}$ Neng Djubaidah, Pencatatan Perkawinan..., 151.

${ }^{31} \mathrm{M}$. Atho' Muzhar, Membaca Gelombang Ijtihad; Antara Tradisi dan Liberasi (Jakarta: Titian Ilahi Pers, 1998), 180.

${ }^{32}$ Anjuran taat kepada pemerintah atau ulil amri disebut dalam al-Qur'an surah al-Nisa' ayat 59 yang berbunyi:

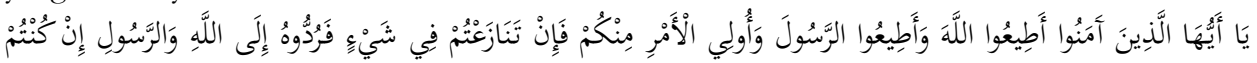

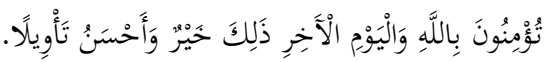

Artinya: Hai orang-orang yang beriman, taatilah Allah dan taatilab Rasaul-Nya dan Ulil amri diantara kamu. Kemudian jika kamu berlainan pendapat tentang sesuatu, maka kembalikanlah ia kepada Allah (al-Qur'an) dan Rasul (sunnabnya), jika kamu benar-benar beriman kepada Allab dan hari akbir. Yang demikian itu lebih utama (bagimu) dan lebih baik akibatnya. 
hal itu dapat dimaklumi karena pada waktu itu umat Islam masih sedikit dan cukup hanya di ingat saja. Sedang Pada zaman kekuasaan kerajaan, Islam semakin luas dan umat Islam semakin banyak, permasalahan-permasalahan umat Islam baik mengenai pidana maupun perdata selalu dihadapkan kepada pemerintah (raja), maka sejak zaman kerajaan Umayah maupun Abbasiyah sudah memulai mengenai keperdataan serta menyelesaikannya melalui pengadilan, terbukti dengan putusan-putusan qậ $i$ mengenai perdata, karena jika tidak dicatatkan dengan baik dan rapi akan menimbulkan kemudaratan bagi kelangsungan kehidupan rumah tangga. ${ }^{33}$

Pencatatan perkawinan di Indonesia merupakan aturan perundangundangan yang statusnya mengikat kepada warga negaranya. Pemegang kekuasaan tertinggi di Indonesia adalah presiden, dapat dikatakan bahwa adanya jajaran kepemerintahan di Indonesia bisa disebut sebagai ulil amri. Ahmad Muțofa al-Marâghi menjelaskan yang dimaksud "ulil amri" adalah pemerintah (pemimpin). Baik pemerintah tersebut yang tertinggi atau pemerintah yang ada di bawahnya, dimana tugasnya adalah memelihara ke maslahatan umat manusia. Dengan demikian aturan-aturan yang dibuat oleh pemerintah untuk kemaslahatan manusia atau rakyatnya wajib ditaati selama aturan-aturan tersebut tidak bertentangan dengan al-Qur'an dan al-Hadis. ${ }^{34}$

Sejatinya kebijakan seorang pemimpin pada rakyatnya harus berdasarkan kemaşlahatan, hal ini seperti yang dijelaskan dalam qawaid alfiqhiyah:

\section{kemaslahatan". 35 \\ "Kebijakan seorang pemimpin kepada rakyatnya harus berdasarkan}

Banyak kemaslahatan yang ada di dalam pencatatan perkawinan utamanya bagi seorang istri dan anak yang lahir dari perkawinan tersebut, serta harta dari keduanya. Selain ketaatan terhadap pemerintah sebagai jelmaan fungsi dari ulil amri, para pakar hukum juga meng-qiyas $\hat{s}^{36}$ adanya

\footnotetext{
${ }^{33}$ Ghufron Maksum, "Telaah Kritis Terhadap Praktik Perkawinan di Bawah Tangan di Indonesia", Kordinat, Vol. XVI, No. 1 (April, 2017), 74.

${ }^{34}$ Ahmad Muțofa al-Marâghi, Tafsîr al-Marâghi, Juz. 5 (Mesir: t.p., 1946), 72.

${ }^{35} \mathrm{Abi}$ Bakar bin Abi al-Qâsim al-Ahdal, al-Farâid al-Babiyah 'ala Nażmi Qawâid al-Fiqhiyah (Pasuruan: Pustaka Sidogiri, 2009), 73.

${ }^{36}$ Qiyâs merupakan suatu cara penggunaan ra'yu untuk menggali hukum shara' dalam hal-hal yang naş al-Qur'an dan hadis tidak menetapkan hukum secara jelas. Pada dasarnya ada dua macam cara penggunaan ra'yu, yaitu: Pertama; penggunaan ra'yu yang masih merujuk kepada naş. Kedua; penggunaan ra'yu secara bebas tanpa mengaitkannya kepada naş. Makna qiyâs (قياس) sendiri قدر (mengukur), secara etimologi qiyâs (قياس) التقدير adalah (mengetahui ukuran dari adanya sesuatu). Sedangkan definisi qijâs secara istilah menurut al-Qâḍi al-Bâqilâni adalah:
} 
pencatatan perkawinan dengan ayat mudâyanah yaitu surah al-Baqarah ayat 282 yang mengisyarahkan adanya bukti tertulis dalam hal hutang pitang.

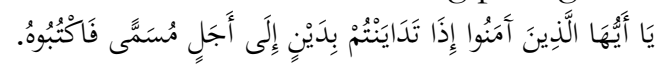

Artinya: 'Hai orang-orang yang beriman, apabila kamu bermua'amalab tidak secara tunai untuk waktu yang ditentukan, hendaklah kamu menuliskannya. ${ }^{37}$

Dilihat dari bentuknya ayat di atas menunjukkan kata perintah (Amar). Pada dasarnya kalimat perintah (Amar) menunjukkan pada sesuatu yang wajib, kecuali ada qainah yang menunjukkan perubahan dari wajib kepada hukum yang lain, seperti sunnah, mubâh, menakut-nakuti (indhar dan tah did), do'a dan tajjî: ${ }^{38}$ Untuk meng-qiyâs pencatatan perkawinan kepada pencatatan transaksi hutang-piutang, maka harus terpenuhi semua rukunrukunya. Rukun qiyâs sendiri terdiri dari empat unsur 1. Asal; 2. Furu'; 3. Hukum Assal; dan 4. Tllat Hukum. ${ }^{39}$

Berdasarkan rukun qiyâs di atas dapat dipahami bahwa:

1. Asal (pokok tempat meng-qiyâs-kan sesuatu): dalam hal ini yang di maksud Assal adalah pencatatan transaksi hutang-piutang yang terdapat dalam surah al-Baqarah ayat 282.

2. Furu' (cabang): adanya anjuran yang berupa perintah melakukan pencatatan perkawinan.

3. Hukum Assal: anjuran atau petunjuk pada surah al-Baqarah ayat 282 berkenaan dengan transaksi hutang-piutang.

4. Illat Hukum: dalam hal ini 'illat-nya adalah transaksi. Yaitu transaksi dalam pernikahan yang berupa penyerahan seorang wali atas anak perempuannya.

Adanya pencatatan perkawinan yang diperoleh melalui metode qiyâs, dapat digolongkan pada pembagian qiyâs musawi karena illat pada cabang sama bobotnya dengan bobot 'illat yang terdapat pada $A s$ sal yaitu 'illat hukum dianjurkannya mencatat pernikahan yang merupakan cabang dari dianjurkannya mencatat transaksi hutang-piutang dalam surah al-Baqarah ayat 282 .

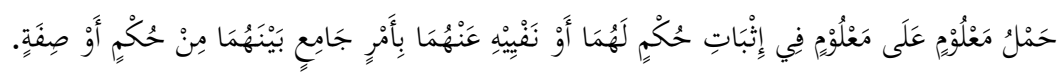

"Menyamakan sesuatu yang diketahu dengan sesuatu yang lain dalam menetapkan hukum diantara keduanya atau meniadakannya dengan mempertimbangkan hal yang sama dari keduanya baik dalam segi hukum atau sifatnya”. Lihat: Amir Syarifuddin, Ushul Fiqh, Juz. 1 (Jakarta: Kencana Prenada Media Group, 2008), 316. Bandingkan Wahbah al-Zuhaili, Uşûl alFiqh al-Islâmî, Juz. 1 (Damaskus: Dar al-Fikr, 1986), 601.

${ }^{37} \mathrm{Al}$-Qur'ân, 2:282.

${ }^{38}$ Wahbah al-Zuhaili, al-Wajì fì Ușul al-Figh (Beirut: Dar al-Fikr, 1999), 211.

${ }^{39}$ Abdul Wahhab Khallâf, Tlmu Ușul al-Fiqh (Kairo: Maktabah al-Da’wah al-Islamiyah, t.t.), 52. 
Berdasarkan penjelasan yang ada, menunjukkan bahwa adanya pencatatan perkawinan merupakan hal yang sangat dianjurkan dalam sebuah perkawinan, mengingat banyaknya hal mudarat dari adanya perkawinan yang tidak dicatatkan. Anjuran pencatatan perkwinan ditunjukkan dengan adanya ketaatan kepada pemerintah (ulil Amri), serta adanya anjuran langsung dari Rasulullah SAW. melalui beberapa hadisnya untuk mengumumkan pernikahan (i'lân al-nikâh) dan walìmah (perayaan pernikahan) yang kemudian harus dipandang sebagi bentuk sederhana dari pencatatan perkawinan. Selain hal tersebut adanya pencatatan perkawinan juga bisa ditinjau melalui metode qiyâs, yaitu meng-qiyâs pencatatan perkawinan dengan transaksi jual beli yang tergolong qiyâs musawit ${ }^{40}$.

\section{Relevansi I'lân al-Nikâh dengan Pencatatan Perkawinan}

Pengakuan dan jaminan hak pernikahan di masa Nabi Muhammad SAW. cukup dengan pengumuman (ilân al-nikâh) kepada masyarakat setempat. Namun seiring dengan perkembangan masyarakat, kemajuan administrasi dan ketatanegaraan, bentuk pengakuan masyarakat dan penjaminan hak juga mengalami perkembangan. Bentuk pengakuan dan jaminan ini di masa sekarang muncul dalam bentuk tulisan, berupa akta nikah. Maka akta nikah merupakan bentuk pengakuan masyarakat dan jaminan hak di masa sekarang. Dengan ungkapan lain, konteks dari pengumuman kepada masyarakat (i'lân al-nikâh) sebagai sarana pengakuan dan penjaminan hak bagi masyarakat komunal yang terbiasa dengan lisan. Sementara konteks akta nikah juga sebagai sarana pengakuan dan penjaminan hak bagi masyarakat secara tertulis.

Khoiruddin Nasution menyatakan bahwa minimal ada tiga hal yang dapat diambil sebagai inti dari sejumlah sunnah Nabi yang memerintahkan agar mengadakan pengumuman (i’ân al-nikâhh). Yaitu; Pertama, bahwa perkawinan masuk urusan publik yang siapapun sepantasnya mengetahui, baik pihak yang secara langsung berkepentingan dengan perkawinan maupun masyarakat umum yang kepentingannya tidak langsung. Kedua, pengetahuan publik itu diharapkan sebagai saranan pengakuan dan penjaminan hak, baik hak pihak yang melakukan perkawinan (pasangan suami-isteri, dan anakanak) maupun hak masyarakat untuk terjamin dari perbuatan fitnah. Ketiga, bentuk pengakuan masyarakat dan penjaminan hak ini muncul dalam bentuk pengumuman (i'lân al-nikâh, walimah dan sejenisnya), dan saksi. ${ }^{41}$

${ }^{40}$ Qiyâs musawi adalah Qiyâs yang berlakunya hukum pada furu' sama keadaannya dengan berlakunya hukum pada așal karena kekuatan 'illat-nya sama. Lihat Amir Syarifuddin, Ushul Fiqh, Juz. 1 (Jakarta: Kencana Prenada Media Group, 2008), 390.

${ }^{41}$ Khoiruddin Nasution, Hukum Perdata (Keluarga) Islam Indonesia dan Perbandingan Hukum Perkawinan di Dunia Muslim (Yogyakarta: ACAdeMIA+Tazzafa, 2008), 366. 
Lebih lanjutnya Khoiruddin Nasution menyatakan ada perubahan illah yang sama di masa Nabi SAW. dengan masa sekarang, sesuai dengan perkembangan dan perubahan zaman. 'illah dari i'lân al-nikeâh, walimah dan adanya saksi yang berlaku di zaman Nabi Muhammad SAW. adalah pengakuan masyarakat dan penjaminan hak. Sementara bentuk pengakuan dan jaminan hak untuk masa sekarang tidak cukup lagi kalau hanya dengan i’lân al-nikâh, walimah dan sejenisnya, tetapi juga dibutuhkan bukti tertulis (akta nikah). ${ }^{42}$

Berdasarkan hal tersebut, dapat dikatakan bahwa keberadaan akta nikah secara hukum memang peranan yang sangat penting, khususnya dalam upaya mempertahankan dan melindungi hak-hak seseorang serta untuk membuktikan bahwa suatu peristiwa hukum telah dilakukan. Oleh karena itu, ketika terjadi tuntutan ataupun gugatan dari pihak lain tentang keabsahan suatu perbuatan hukum, maka peranan alat bukti (akta nikah) menjadi sangat penting. Maka disinilah letak relevansi ilân al-nikâh dengan pentingnya pencatatan perkawinan.

\section{Pencatatan Perkawinan dalam Sudut Pandang Sadd al-Dharî’ah}

Syiar fiqh berkenaan dengan i'lân al-nikâh (mengumumkan Pernikahan) dengan spirit yang terkandung di dalamnya yang mempunyai tujuan untuk mengumumkan terjadinya perkawinan ke khalayak umum, mengantisipasi terjadinya nikâh siri (rahasia) dan nikah di bawah tangan serta mencegah terjadinya prasangka perzinahan. Hal ini menunjukkan bahwa pencatatan perkawinan dalam fiqh secara implisit sudah tersirat dalam i'lân al-nikeâh (mengumumkan Pernikahan).

I'lâ al-nikeâh (mengumumkan Pernikahan) yang kemudian dalam fiqh diwujudkan kedalam bentuk perayaan walimah merupakan sarana pengakuan dan jaminan hak masyarakat. Namun seiring berkembangnya kemajuan administrasi dan ketatanegaraan, bentuk pengakuan dan penjaminan hak di masa sekarang muncul dalam bentuk tulisan, yaitu pencatatan perkawinan berupa akta nikah. Sehingga, akta nikah menjadi salah satu bukti otentik dalam terjadinya akad nikah.

Mengenai tujuan diundang-undangkannya sebuah pencatatan perkawinan adalah mewujudkan tertibnya sebuah perkawinan. Pencatatan perkawinan sendiri merupakan suatu bentuk kegiatan administratif dalam keperdataan yang bertujuan sebagai langkah preventif (pencegahan) untuk menolak dampak negatif yang akan ditimbulakan dari pernikahan yang tidak dicatat (nikâh siri dan nikah di bawah tangan).

\footnotetext{
${ }^{42}$ Khoiruddin Nasution, Huk.um Perdata (Keluarga) Islam..., 368.
} 
Mengenai tujuan dilakukannya pencatatan perkawinan hal ini dituangkan dalam pasal 5 ayat (1) Kompilasi Hukum Islam (KHI) yang berbunyi:

\section{"Agar terjamin ketertiban perkawinan bagi masyarakat Islam setiap perkawinan harus dicatat". 43}

Neng Djubaidah mengungkapkan bahwa istilah "harus dicatat" dalam pasal 5 ayat (1) Kompilasi Hukum Islam (KHI) hanya bertujuan untuk menjamin ketertiban perkawinan bagi masyarakat Islam semata. ${ }^{44}$

Hal mudarat yang akan ditimbulkan dari perkawinan yang tidak dicatatakan adalah: Pertama, perkawinan yang dilakukan tidak mempunyai kekuatan hukum. ${ }^{45}$ Kedua, anak Hanya Mempunyai Hubungan Perdata dengan Ibu dan Keluarga Ibu. ${ }^{46}$ Ketiga, isteri dan Anak Tidak Berhak Menuntut Nafkah atau Warisan. ${ }^{47}$ Keempat, konsekuensi yang akan terjadi dari pernikahan yang tidak dicatat lama-kelamaan akan merembet dan berdampak pada psikologis seorang isteri dan anak yang dilahirkan. Atas dasar inilah, adanya pencatatan perkawinan merupakan saddan li al-dharîab.

Sadd al-dhari'a h $^{48}$ merupakan salah satu metode dalam menetapkan hukum (Istinbaț al-bukmi) yang merupakan bagian dari kajian uşul figh. Menurut imam al-Shawkânî berkenaan dengan al-dharỉah adalah:

\footnotetext{
${ }^{43}$ Tim Redaksi Nuansa Aulia, Kompilasi Hukum Islam..., 2.

${ }^{44}$ Neng Djubaidah, Pencatatan Perkawinan..., 219.

${ }^{45}$ Lihat: Pasal 6 ayat (2) Kompilasi Hukum Islam.

${ }^{46}$ Secara garis besar, perkawinan yang tidak dicatatkan sama saja dengan membiarkan adanya hidup bersama di luar perkawinan, dan ini sangat merugikan kepada pihak yang terlibat (terutama perempuan), terlebih lagi kalau sudah ada anak-anak yang dilahirkan. Mereka yang dilahirkan dari orang tua yang hidup bersama tanpa dicatatkan perkawinannya, adalah anak luar pernikahan yang hanya mempunyai hubungan keperdataan dengan ibunya, dalam artian tidak mepunyai hubungan hukum dengan bapaknya. Dengan kata lain secara yuridis tidak mepunyai bapak. Lihat: Vivi Kurniawati, Nikah Siri (Jakarta: Rumah Fiqih Publishing, 2019), 30.

${ }^{47}$ Seorang isteri kedudukannya tidak dianggap isteri yang sah serta seorang anak secara keperdataan dianggap tidak mempunyai hubungan hukum dengan bapaknya, maka prihal yang berhubungan dengan nafkah dan waris bukanlah tanggung jawab suami atau bapak.

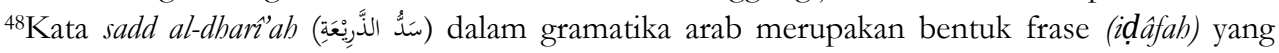

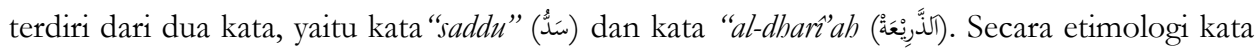

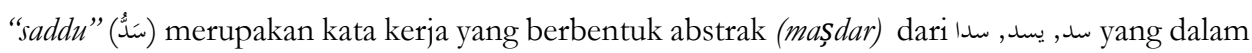
bahasa arab digunakan untuk arti menutup, mengunci, membuntui atau menyumbat. Sedangkan kata kata "al-dharîa" (أنَّرِيْعَة) sendiri merupakan bentuk kata benda (isim) yang bersifat tunggal yang berarti perantara, sarana atau wasilah. Lihat: Atabik Ali \& Ahmad Zuhdi Muhdlor, Al-Aṣrí; Kamus Kontemporer Arab Indonesia (Yogyakarta: Multi Karya Grafika, t.t.), 929 dan1053.
} 


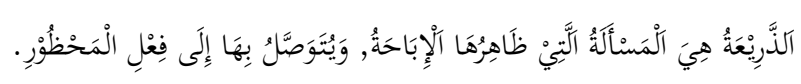

“Al-dharîah ialah sebuah permasalahan atau perkara yang secara eksplisit (Zâhir) diperbolebkan, namun dijadikan perantara (waşillah) untuk pekerjaan yang dilarang (al-mahzûrr)" ${ }^{49}$

Bisa dipahami bahwa istilah sadd al-dhari"ab adalah pembahasan seputar upaya untuk menghalangi dan memblokade semua akses dan kemungkinan dari suatu perbuatan tertentu yang pada dasarnya diperbolehkan maupun dilarang untuk mencegah terjadinya segala jenis kerusakan dan kemudaratan.

Contoh, pada dasarnya menjual anggur adalah mubâh (boleh), karena anggur adalah buah-buahan yang halal dimakan. Akan tetapi menjual anggur kepada orang yang akan mengolahnya menjadi minuman keras menjadi terlarang. Perbuatan tersebut terlarang, karena akan menimbulkan mafsadah. Larangan tersebut untuk mencegah agar orang jangan membuat minuman keras dan agar orang terhindar dari minuman-minuman yang memabukkan, dimana keduanya merupakan mafsadab. ${ }^{50}$

Berdasarkan definisi sadd al-dhari'ah tersebut, sangat jelas bahwa pada dasarnya sebuah perkawinan (tidak dicatat) adalah pekerjaan yang sahsah saja dikerjakan selama terpenuhi syarat dan rukunya, namun karena perkawinan (tidak dicatat) seringkali menimbulkan dampak negatif bahkan menjadi perantara (waşîlah) untuk pekerjaan yang dilarang (al-mahẓ̂ur). Maka melakukan pernikahan dengan cara tidak dicatat pada instansi yang berwenang hukumnya adalah haram. Keharaman tersebut disebabkan oleh dampak yang ditimbulkan dari pernikahan yang tidak dicatat. Hal ini sesuai dengan qawaid al-usuliyah yang berupa:

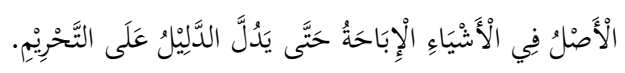

\footnotetext{
${ }^{49}$ Terkait dengan penggunaan sadd al-dhari'ah sebagai metode menetapkan hukum (Istinbat albukmi) masih terdapat perbedaan dikalangan ulama. Dimana ada yang menerima seutuhnya, seperti ulama Mâlikîyah dan Hanâbilah dan ada yang menolak sepenuhnya seperti ulama Zâhiriyah. Namun, ada juga yang tidak menerima sepenuhnya dalam artian menerima dalam hal tertentu saja seperti ulama Hanâfiyah dan ulama Shâfi'îyah. Lihat: Wahbah al-Zuhailî, Uşûl al-Fiqh al-Islâmî, Juz. 2 (Damaskus: Dar al-Fikr, 1986), 873. M. Asrorun Ni'am Sholeh, Metodologi Penetapan Fatwa Majelis Ulama Indonesia; Penggunaan Prinsip Pencegahan dalam Fatwa (t.tp: Emir, 2016), 39. Amir Syarifuddin, Ushul Figh, Juz. 2 (Jakarta: Kencana Prenada Media Group, 2008), 431. Bandingkan Muhammad bin 'Ali al-Shawkânî, Irshâd al-Fuhûl ilâ Tahqî́i al-haqqi min Ilmi al-Uşûl, Juz. 2 (Riyad: Dâr al-Fadilah, 2000), 1007.

${ }^{50}$ Abd. Rahman Dahlan, Ushul Fiqh (Jakarta:Amzah, 2014), 196.
} 
"Hukum asal segala sesuatu itu adalab boleh. Akan menjadi haram, bila ada dalil yang menunjukekan indikasi keharaman". ${ }^{51}$

Kaidah ini merupakan kaidah yang dipakai oleh imam Shafi'i dengan membedai qawâid al-ușuliyah milik imam Abu Hanîfah ${ }^{52}$. Berdasarkan qawaid al-ușuliyah tersebut jelas bahwa hukum asal dari perkawinan (tidak dicatat) adalah mubâh (boleh) akan tetapi menjadi hukum haram apabila ada indikasi keharaman.

Terkait dengan masalah haram apabila menimbulkan dampak negatif (mudarat), K.H. Ma'ruf Amin, forum ijtima' ulama komisi fatwa menegaskan bahwa hukum nikah yang awalnya sah karena memenuhi syarat dan rukun nikah menjadi haram karena ada yang menjadi korban. Dengan demikian, "Haramnya itu datang belakangan. Pernikahan sendiri tidak batal, tetapi menjadi berdosa karena ada orang yang diterlantarkan, sehingga dia berdosa karena mengorbankan istri atau anak. Sab tapi haram kalau sampai terjadi korban. Inilah uniknya". 53

Dilihat dari unsur atau komponen sadd al-dharîah, yaitu al-wasilah (sarana atau perantara), al-ifda' (penghubung antara sarana dan tujuan) dan al-mutawassal ilaih (yang diantarkan/tujuan). ${ }^{54}$ Adanya perbuatan "tidak mencatat perkawinan" merupakan "al-wasilah" (sarana atau perantara) dalam menimbulkan terjadinya hal negatif (mudarat) dengan sendirinya. Sedangkan al-iff $a$ ' atau penghubung antara al-wasilah (perantara) dan al-mutawassal ilaih (tujuan) adalah "proses berlangsungnya sebuah perkawinan yang tidak dicatat hingga menimbulkan dampak negati atau mudarat”. Adapun yang tergolong

${ }^{51}$ Jalâluddin Abd Rahman bin Abi Bakar al-Suyûț̂i, al-Ashbah wa al-Naẓâir (Semarang: Pustaka Semarang, t.t. ), 43.

${ }^{52}$ Qawaìd al-uṣuliyah yang digunakan imam Abu Hanîfah berkenaan dengan asal segala sesuatu adalah:

$$
\text { الأصل فيها التحريم حتى يدل الدليل على ألإباحة. }
$$

"Hukum asal segala sesuatu itu adalah haram. Akan menjadi halal, bila ada dalil yang menunjukkan indikasi kehalalan”. Lihat: Jalâluddin Abd Rahman bin Abi Bakar al-Suyûțî, alAshbah wa al-NaZâir (Semarang: Pustaka Semarang, t.t. ), 43.

${ }^{53}$ M. Asrorun Ni'am Sholeh, Metodologi Penetapan Fatwa...., 223.

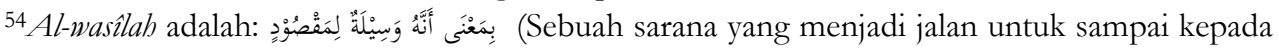
tujuan) Hukum asal dari al-wasîlah adalah boleh. Al-If̣̣a' dapat diartikan sebagai "dugaan kuat

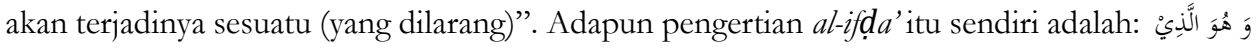

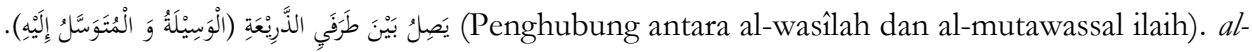
mutawassal ilaih (tujuan) atau disebut juga dengan mutadharri' ilaih. Mengenai pengertian al-

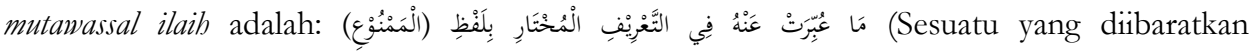
menggunakan definisi lafaz "المنوع" atau sesuatu yang dilarang) Lihat: Muhammad Hishâm alBurhânî, Sadd al-Dharầîfi Shariat al-Islâmiyah (Damaskus: Dâr al-Fikr, 1985), 102-121. 
al-mutawassal ilaih (tujuan) adalah "dampak negati atau mudarat" seperti tidak diakuinya seorang isteri sebagai isteri yang sah dan pernikahnya tidak memiliki kekuatan hukum, adanya anak yang tidak diakui keperdataannya sebagai hasil perkawinan yang sah (anak zina).

Berkenaan dengan adanya kerusakan (mudarat) yang ditimbulakan dari praktik perkawinan yang tidak dicatat seperti yang telah dijelaskan di atas. Maka kualitas kerusakan (mudarat) yang ditimbulkan tergolong pada Kathir (Sering). Yaitu, Perbuatan yang kemungkinan besar membawa kepada kerusakan (mafsadab). Praktik perkawinan yang tidak di catat secara sekala besar mempunyai dampak negatif utamanya dalam hal keperdataan.

Berdasarkan penjelasan di atas serta adanya kecenderungan terjadinya kemudaratan dalam praktik perkawinan yang tidak dicatat, maka sangatlah jelas tujuan diadakan keharusan pencatatan perkawinan melalui peraturan perundang-undangan yaitu merupakan langkah preventif (pencegahan) untuk menolak dampak negatif (mudarat) yang terjadi. Dengan demikian diharamkan melakukan perkawinan yang tidak dicatatkan dan diwajibkan mencatatkan perkawinan pada pihak berwenang karena saddan li al-dharìah.

Berdasarkan pembahasan di atas, bukanlah sebuah hal yang keliru jika adanya "pencatatan perkawinan" dikaji dengan menggunakan metode sadd al-dharîah sebagai langkah preventif dalam mencegah dampak mudarat dari "pernikahan yang tidak dicatat" (nikah di bawah tangan dan nikâh sirn). Hal ini sesuai dengan pendapat imam al- Shâţibî yang mengemukakan, tiga syarat yang harus dipenuhi dalam mengimplementasikan sadd al-dharî ah pada suatu perbuatan, sehingga yang semula di perbolehkan menjadi dilarang, yaitu;

1. Perbuatan tersebut bisa membawa kepada kemafsadatan;

2. Kemafsadatan yang ditimbulkan lebih kuat dari kemaslahatan yang diperoleh;

3. Unsur kemafsadatannya ternyata lebih banyak. ${ }^{55}$

\section{Kesimpulan}

Perintah pencatatan perkawinan dalam fiqh terkandung secara implisit melalui hadis Nabi Saw, berkenaan dengan I'lâ al-nikâh (mengumumkan Pernikahan), walimah serta dalam surat al-Baqarah ayat 282 tentang pencatatan dalam bidang muamalah. Sedangkan perintah pencatatan perkawinan dalam Undang-Undang Perkawinan (UUP) terkandung secara eksplisit. Kedua nya mepunyai tujuan yang sama, yaitu untuk mendapat pengakuan dari masyarakat. Namun jika melihat dampak mudarat dari

${ }^{55}$ M. Asrorun Ni'am Sholeh, Metodologi Penetapan Fatwa..., 34. 
"pernikahan yang tidak dicatat" (nikah di bawah tangan dan nikâh siri) serta demi ketertiban sebuah perkawinan maka hukum mencatat perkawinan adalah wajib sebagai langkah preventif saddan li al-dhari"ab (memblokade jalan kerusakan).

\section{Daftar Pustaka}

Al-'Asqalânî, Ibn Hajar. t.t. Bulùgh al-Marâm fì Adillat al-Aḥkâm. Surabaya: Nurul Huda.

Al-Ahdal, Abi Bakar bin Abi al-Qâsim. 2009. al-Farâid al-Babiyah 'alâ NaZmi Qawaid al-Fiqhiyah. Pasuruan: Pustaka Sidogiri.

Al-Burhânî, Muhammad Hishâm. 1985. Sadd al-Dharầî fi Sharîat al-Islâmiyah. Damaskus: Dâr al-Fikr.

Ali, Atabik. \& Muhdlor, Ahmad Zuhdi. t.t. Al-Assrí; Kamus Kontemporer Arab Indonesia. Yogyakarta: Multi Karya Grafika.

Al-Kaḥlanî, Muhammad bin Ismầil. t.t. Subûl al-Salâm Sharh Bulùgh al-Marâm fî̀ Adillat al-Aḥkâm. Juz. 3. Beirut: Dar al-Fikr.

Al-Marâghî, Ahmad Muțofa. 1946. Tafsìr al-Marâghi. Juz. 5. Mesir: t.p..

Al-Qur'ân.

Al-Shawkânî, Muhammad bin 'Ali. 2000. Irshâd al-Fuḥ̂ul ilâ Tahqîq al-baqq min Ilm al-Uşûl, Juz. 2. Riyad: Dar al-Fadilah.

Al-Suyûtịî, Jalâl al-Dîn Abd Rahmân bin Abî Bakar. t.t. al-Ashbah wa al-Nazâair. Semarang: Pustaka Semarang.

Al-Zuhailî, Wahbah. 1986. Uşû̉ al-Fiqh al-Islamî. Juz. 1\&2. Damaskus: Dar alFikr. . 1999. al-W ajî̀ fî̀ Ușul al-Fiqh. Beirut: Dar al-Fikr.

Dahlan, Abd. Rahman. 2014. Ushul Fiqh. Jakarta: Amzah.

Departemen Pendidikan Nasional. 2008. Kamus Besar Bahasa Indonesia. Jakarta: Gramedia Pustaka Utama. 
Djubaidah, Neng. 2012. Pencatatan Perkawinan dan Perkawinan Tidak Dicatat Menurut Hukum Tertulis di Indonesia dan Hukum Islam. Jakarta: Sinar Grafika.

Firdaus, Ali. 2017. Pelaksanaan Tugas Pembantu Pegawai Pencatat Nikah Pasca Instruksi Dirjen Bimas Islam Nomor DJ.II/1 Tahun 2015. Ijtimaiyya: jurnal Pengembangan Masyarakat Islam, (Online), Vol. 10, No. 2, (http://ejournal.radenintan.ac.id/index.php/ijtimaiyya/article/view/2 $\underline{363}$, diakses 3 Juni 2019).

https://m.liputan6.com/showbiz/read/4048015/nikita-mirzani-tak-kapokkapok-menikah-siri, diakses 23 September 2019.

Ibn Ḥamzah, Shams al-Dîn Muhammad bin Abi al-'Abbâs. 2003. Nihâyah alMuhtaj ilâ Sharḥ al-Minhâj. Juz.6. Beirut: Dar al-Kitâb al-'Tlmiyah.

Khallâf, Abdul Wahhab. t.t. Tlmu Uṣul al-Fiqh. Kairo: Maktabah al-Da’wah alIslamiyah.

Kurniawati, Vivi. 2019. Nikah Siri. Jakarta: Rumah Fiqih Publishing.

Maksum, Ghufron. 2017. Telaah Kritis Terhadap Praktik Perkawinan di Bawah Tangan di Indonesia. Kordinat, (Online), Vol. XVI, No. 1, (http://journal.uinjkt.ac.id/index.php/kordinat/article/view/6455/39 51, diakses 7 Juni 2019).

Marsal, Arif. \& Parlyna, Ryna. 2015. Pencatatan Perkawinan; Antara Rukun Nikah dan Syarat Administratif. an-Nur, (Online), Vol. 4, No.1, (http://ejournal.uin.suska.ac.id/index.php/annur/article/download/2 052/1392, diakses 21 Oktober 2018).

Muhajarah, Kurnia. 2015. Secercah Pandang mengungkap Nikah Sirri di Indonesia. Sawwa, (Online), Vol. 10, No. 2 (http://journal.walisongo.ac.id/index.php/sawwa/article/download/1 434/1053, diakses 19 September 2019).

Munawwir, Ahmad Warson. 1997. al-Munawir; Kamus Arab-Indonesia. Surabaya: Pustaka Progressif.

Mustika, Dian. 2015. Pencatatan Perkawinan dalam Undang-Undang Hukum Keluarga di Dunia Islam. Inovatif; Jurnal Imu Hukum, (Online), Vol. 4. 
No. 5, (https://online-journal.unja.ac.id/jimih/article/view/534, diakses 9 Juni 2019).

Muzhar, M. Atho'. 1998. Membaca Gelombang Ijtibad; Antara Tradisi dan Liberasi. Jakarta: Titian Ilahi Pers.

Nasution, Khoiruddin. 2008. Hukum Perdata (Keluarga) Islam Indonesia dan Perbandingan Hukum Perkawinan di Dunia Muslim. Yogyakarta: ACAdeMIA+Tazzafa.

Ni'am, M. Asrorun. 2016. Metodologi Penetapan Fatwa Majelis Ulama Indonesia; Penggunaan Prinsip Pencegahan dalam Fatwa. t.tp: Emir.

Nuruddin, Amiur dan Tarigan, Azhari Akmal. 2004. Hukum Perdata Islam di Indonesia; Studi Kritis Perkembangan Hukum Islam dari Fikib, UU No. 1/1974 sampai KHI. Jakarta: Kencana.

Pulungan, Nur Azizah. 2018. Haruskah ada Walimab?. Jakarta: Rumah Fiqih Publishing.

Susanti, Dyah Ochtorina. \& Shoimah, Siti Nur. 2016. Urgensi Pencatatan Perkawinan (Perspektif Utilities). Rechtidee, (Online), Vol. 11. No. 2, (http://www.researchgate.net/publication/313455671 Urgensi Penca tatan Perkawinan Perspektif Utilities, diakses 7 Juni 2019).

Syahuri, Taufiqurrohman. 2013. Legislasi Hukum Perkawinan di Indonesia; ProKontra Pembentukannya Hingga Putusan Mabkamah Konstitusi. Jakarta: Kencana Prenada Media Group.

Syarifuddin, Amir. 2011. Ushul Fiqh. Juz. 1\&2. Jakarta: Kencana Prenada Media Group. . 2014. Hukum Perkawinan Islam di Indonesia; Antara Fiqh Munakahat dan Undang-Undang Perkawinan. Jakarta: Kencana Prenada Media Group.

Team Citra Umbara. 2017. Undang-Undang RI Nomor 1 Tabun 1974 Tentang Perkawinan \& Kompilasi Hukum Islam. Bandung: Citra Umbara.

Tim Redaksi Nuansa Aulia. 2015. Kompilasi Hukum Islam. Bandung: Nuansa Aulia. 
Undang-Undang Republik. Indonesia Nomor 22 Tabun 1946 Pasal 1 Ayat (1) Tentang Pencatatan Nikah, Talak dan Rujuk.

Wizarah al-Auqâf wa al-Shu'ûn al-Islâmiyah. 2002. al-Mausu'ah al-Fiqhiyah, Juz. 41. Kuwait: Wizarah al-Auqâf wa al-Shu'ûn al-Islâmiyah.

Mohsi, Mohsi. "PENCATATAN PERKAWINAN SEBAGAI REKONSEPTUALISASI SYSTEM SAKSI PERKAWINAN BERBASIS MASLAHAH." Al'Adalah: Jurnal Syariah dan Hukum Islam 4.2 (2019): 134-148.

Mohsi, Mohsi. "KONSTRUKSI HUKUM PERCERAIAN ISLAM DALAM FIQH INDONESIA." Ulumuna: Jurnal Studi Keislaman 1.2 (2015). 